\title{
Mundus vult decipi
}

\author{
John A. Hoskins
}

Reigate, UK

It seems to be a basic characteristic of the human race that they wish to be deceived. To this end their gullibility knows no bounds. Nowhere is this more true than in the matter of beliefs. When a belief is offered it is accepted gratefully. Unfortunately there is little in the collective psyche that distinguishes between that which should be taken on trust, like religion, and that for which a degree of scientific proof is required. It is surely sad that so many people have absolute faith in what they are told however ridiculous it might seem. People know that politicians lie yet they believe the pronouncements of Government. Why should this be? It is not a new phenomenon and must go back millennia. Perhaps it originated as a protective device for an emerging societal structure. Belief is a powerful glue to hold a group together.

Religion once held the key and probably still does for many people. A collective belief in the unknowable. Man, that etymologically exact if politically incorrect description of the human race and all things closely associated, stands in the middle of the beliefs. The centre of the universe and the point from which all beliefs are measured. Up, down, left, right, heaven, hell, good and evil, black and white, they are a readily extendible list of dichotomies. The first ones begat the last; take the dichotomy of good and evil. It is not considered 'social' to make your own mind up about such things. Beliefs can lead to actions. Therefore, we like to be told what is approved of as good and what is proscribed or bad. In the days before newspapers and radio and television there was little problem. The common herd was informed and controlled largely by the clergy backed with the rule of law to ensure that the flock did not stray too far from the parish. Information came from the pulpit and the manor house. The congregation was told what to believe and what not to believe and openly, at least, they accepted this. Not to do so was often a punishable offence in Christian religions and is so today where the Muslim religion holds sway. Now that religious influence is fading, at least in the Western world, other sources of information are required. Something to provide an all-encompassing list of what is good and what is bad; what is to be loved and what is to be feared.

Thank heavens we have the media! They know what is what. They know that good and evil are extremes, the first white, the other black, and that we live in the world between which is composed of shades of grey, neither at one extreme nor the other. Nuances of language allow us to express very precisely our position between these extremes. Unfortunately this dominant factor in modern life whose very being relies so much on language is the one thing that does not allow any shades of grey. The media believe only in black and white. Any information which they communicate is targeted either at one extreme or the other. Truth, needless to say, is the first casualty of media information. The consequence of this is that the precision of language is lost and individuals cannot obtain the proper information needed for them to make up their own mind.

There are many examples of 'extremism' which come within the compass of this journal. One particularly thorny issue is that of carcinogenesis. We know that some chemicals may cause cancer. If we have any scientific

\begin{tabular}{ll}
\hline KARGER & ( ) 2000 S. Karger AG, Basel \\
Fax +4161306 1234 $340-326 \mathrm{X} / 99 / 0085-0277 \$ 17.50 / 0$ \\
$\begin{array}{l}\text { E-Mail karger@karger.ch } \\
\text { www.karger.com }\end{array}$ & $\begin{array}{l}\text { Accessible online at: } \\
\text { www.karger.com/journals/ibe }\end{array}$
\end{tabular}


knowledge we know that the probability that they will do so increases with the dose of the chemical to which the body is exposed. Conversely, with exposure to decreasing amounts the probability that it will have a deleterious effect decreases. There may even be an exposure below which the chemical does not cause cancer, de facto or de jure. That is, the body may detoxify or eliminate the material without any molecular damage occurring or, if such damage does occur, its effect will be on a time scale much greater than that of the life of the person. Although we may not be able to distinguish one of these scenarios from the other overall the event is testable scientifically. Scientific observation can show that at the levels below a putative threshold no effect is observed. But this is science, not belief. The general population is conditioned to black or white answers. If a chemical is carcinogenic, so far as they are concerned any amount of that chemical is a danger. Threshold has no meaning for the man on the Clapham omnibus. Regrettably and unscientifically this is also the view of regulators. However, the volume of scientific evidence that thresholds exist is increasing and some time in the future the regulators may have to bow to its pressure.

Environmental extremism is as absurd as religious extremism was in the middle ages. So, it may not be too absurd to use the same terminology and talk of demons. Carcinogens are demons as are the ill-defined materials known as 'chemicals'. 'The media' and pundits with every level of scientific ignorance tell us that 'chemicals' are bad. Chemicals are poisonous, chemicals are dangerous, chemicals destroy us and our environment. They can appear anywhere but when they are in food they are particularly bad. Unfortunately, any attempt to introduce a degree of rationality into the discussion is doomed to failure. To say that we are made of chemicals, that we live in a chemical world, that we live on a chemical world, carries no meaning for the man in the street. To try and explain that on any plate of food the only things that can be relied on to be safe to eat are those chemicals, natural or synthetic, which are traces of herbicides, pesticides or hormones or those that have E numbers. The rest of the food must be taken on trust. The proposal would be rejected. This aspect of 'chemicals' is one of the great examples of modern gullibility. Currently there is a need to put the word 'organic' in front of a range of foodstuffs. If something is described as organic we have been told to assume that it is good. The argument is simple: 'organic' equates with 'natural'. 'Natural' is also a good thing but encompasses a wider spectrum than 'organic' although the ad-men are moving the two words closer together all the time. Additives of any sort in food, whether deliberate or incidental, natural or artificial, are perceived to be bad. There is little point in trying to explain the work of Bruce Ames and his claims that there are too many rat carcinogens. It is difficult enough explaining to the regulators that just because a chemical causes cancer in a rat when given at extremely high doses and only has an effect at those high doses and none at lower doses that does not mean that that same chemical, at even lower doses, is dangerous to man.

Formaldehyde is a case in point, this is a minor demon. It is a naturally occurring chemical found in the mammalian body and is also a major commodity chemical. It is highly irritant and life span studies on rats showed that exposure to high levels, far higher than humans could tolerate, produced nasal tumours in more than $50 \%$ of the rats exposed. At a lower exposure level only two tumours were observed in 153 rats. No tumours were observed at the lowest exposure concentration or in control rats. This non-linear dose response is striking and suggests a threshold. Further work with rats and monkeys using DNA-protein cross-linking as an end-point also showed a nonlinear response, and that monkeys were less sensitive than rats. The observed data have been used in a linearised multistage model and extrapolated to lower levels of exposure, which is the approach advocated within EPA guidelines for carcinogenic risk assessment. But, in spite of the evidence, the carcinogen label sticks.

Back to the pure and good 'organic' and the struggle against herbicides and pesticides. These chemicals are only latterly an invention of man. Nature has been using them since the beginning of plant and animal life on earth. Just as an animal will try to prevent itself being predated so will a plant. An animal, generally, can move away from the predator, a plant cannot. The plant therefore responds by making itself unattractive to the predator by producing a chemical response which will kill or deter the predator. Many such chemicals are carcinogenic. A plant which is stressed by its environment, by predators, or even after gathering, by long transport or poor storage conditions, will respond by producing 'chemicals' to defend itself. The 'organic' lobby does not want to know that. The aim of synthetic herbicides and pesticides, as with the natural ones is to reduce the stresses in vegetable food stocks. This has the commercial result of improving yields and improving profits and improving quality. The reason that the organic produce succeeds in the market place is because it is grown for consumers rather than supermarkets, and all that that implies. Some cultivars taste better than others. Breeding, or should that be genetic manipulation (another demon and another story), has made them so. 
Demons are all around us. They are so easy to raise and their existence cannot be changed by any rational argument. We may not even investigate whether they are correctly defined. To mention the demon in any but a condemnatory way is to identify yourself as in league with the forces of evil that raised the demon. Don't talk about the terrifying demon asbestos, or frightening metals like lead and say things like: at ambient levels there can be no discernible health effects. It would be a brave person who would try to explain the world conspiracy that decided that the traces of benzene in tobacco smoke or the much larger amounts from fires and petrol-driven vehicles were a danger to the public because benzene is a carcinogen while petrol which contains vastly higher quantities, together with small amounts of other known carcinogens, is not a carcinogen. There is another oil product with some $60 \%$ of benzene in it and this also is not a carcinogen. Other chemical mixtures which contain even $0.1 \%$ of a carcinogen (OSHA rules) have to be described as carcinogens.

The latest on the list of demons is the organo-phosphorus pesticides used for sheep dip. No matter that detailed scientific evidence has not found them to be damaging the people who use them. Nor that they have a long history of success in the role for which they are used. They have been called demons and so they must remain. Neither, it seems, does it matter that the replacements, the pyrethroids, are far more ecologically damaging and their effects less understood on people or the environment than those of the organo-phosphorus compounds. It is not science that is important. A demon has been raised and it may not be put down by scientific argument, by observation, or any other means.

This brings us to the major things which decide whether or not a thing is good or bad, a demon or a boon to society, whether the Pavlovian response should be to drool or to cower. It is commerce. If substitution of one material by another increases profits it is good. Out with chrysotile, in with a range of alternatives. As I noted above when something is judged absolutely necessary to society and profitable to governments and industry alike, something like, say, petrol, then it is commercial and political madness to damn it. Alternatively, it is a common device of governments to dress up trade considerations in the guise of health-based issues. Governments in their role as the electorate's friend like to present a benign face to the people they are governing, the face of deceit is never shown.

How do they get away with it, these pedlars of misinformation? Why do the general public accept nearly every bit of nonsense they are offered? Is it lack of education? The failure of schools to make pupils think about what they are saying, how to develop an argument, or to show comprehension in their writing? There seems to be little attempt to explain that in a world directed by media people should look beyond the stories, beyond the black and white, to try to discern the shades of grey and so arrive at a more rational and realistic 'truth'. Certainly, and sadly, science takes a back seat today in any educational plan. There is no search for the real world or any call for scientific integrity. The result is that people lose the ability to think for themselves, to decide what is right and what is wrong, what is good and what is bad. Today it seems that prejudice always wins over common sense. Rational evidence is rejected in favour of an irrational explanation. We have to live with the fact that the truth will always be sacrificed to the political machinations of a government, but we should understand what is going on. Perhaps the Romans got it right when they said 'the world wants to be deceived'. 